\title{
RELIGIOUS FANATICS THAT BECAME POLITICAL HEROES: THE HISTORICAL DISTORTIONS OF THE BULHOEK MASSACRE
}

\author{
D.H. MAKOBE \\ DOCUMENTATION SERVICE DIRECTORATE, SANDF
}

\begin{abstract}
In die slotartikel word die bronne asook die polemiek rondom die Bulhoekopstand ontleed. Gedurende die sewentigerjare is die opstand beskou as deel van die SuidAfrikaanse swart versetgeskiedenis. Nou word die pleidooi gelewer dat die Bulhoekopstand nie uit ' $n$ politieke oogpunt benader moet word nie maar dat die feite krities ontleed moet word.
\end{abstract}

\section{INTRODUCTION}

Political developments played an important role in shaping the course of South African historiography. This can be illustrated by the use of the concept "People's or Popular History". The term has different meanings depending on the context and who is using it. To many black South Africans in the 1980s it meant the type of history that they would like to see in a post apartheid South Africa. The National Party government, on the other hand, equated People's History with the revolutionary forces trying to overthrow it during the 1980s. This article traces the origins of the concept People's History during the 1930s and 1940s amongst the Afrikaner nationalistic movement and shows how history as a discipline was used to promote Afrikaner nationalism. The article further shows how in the late 1970 s and 1980s, following the 1973 Durban strikes and the Soweto students riots of 1976, the terminology, People's History assumed an entirely different meaning. The main focus of the article is on the historical distortions of the Bulhoek massacre in the 1980 s when historians promoted the strug- gle for national liberation through their work within the context of People's History.

\section{PEOPLE'S HISTORY IN SOUTH AFRICAN HISTORY, 1930-1980}

It can be argued that the origins of the concept "People's History" can be traced back to the 1930s and 1940s in South African history. During this period, the Afrikaner nationalistic movement initiated the idea through their "volksgeskiedenis" which placed the struggles and deeds of the Afrikaners at the core of their history. ${ }^{1}$ The importance of the past was emphasised in near religious terms: the "calling" and "destination" of the Afrikaner people were predetermined by their history and the "volk" therefore had a duty to honour and obey the sanctity of the past. A "volksgeskiedenis" as the historian A. Grundlingh defined it, was "...a history infused with romantic notions of God-fearing, intrepid 19 th century pioneers, great visionary leaders and loyal followers who despite trials and tribulations, established a 'civilized' form of government in the interior." It was a history which stood in contrast to

L. Witz, History of the People, for the People and by the People: A brief examination of the development of Peoples's history in South Africa, 1977-1988, South Africa International, July 1982, p 30. The rise of Afrikaner nationalism in the thirties and forties is well documented. See A. du Toit, Facing up to the future: Some personal reflections on the predicament of Afrikaner Intellectuals in the legitimation crisis of Afrikaner Nationalism and the Apartheid State, Social Dynamics 7, 1981; D. O'Meara, Volkskapitalisme: Class, Capitalism and Ideology in the Development of Afrikaner Nationalism, 1934-1948; T. Dunbar Moodie, The rise of Afrikanerdom: Power, Apartheid and the Afrikaner Civil religion; $\mathrm{H}$. Adam and $\mathrm{H}$. Giliomee, The Rise and Crisis of Afrikaner Power. 
the prevailing imperialist view of the time in which South Africa only featured as a part of the British Empire, or the emerging liberal perspective which had a more composite view of South African society and its past". ${ }^{2}$ Afrikaans speaking historians within Afrikaans universities promoted this nationalistic history. The University of Stellenbosch, the home of the Afrikaans intellectual elite at the time, provided the direction. In showing the importance of the University of Stellenbosch to the Afrikaner during this period, Grundlingh compared it to other universities in the western world. He stated that ".... what the Oxbridge universities were to the national life of Britain and the Ivy league universities were to America, Stellenbosch was to the Afrikaner." ${ }^{3}$

The coming to power of the National Party government in 1948 helped to consolidate "volksgeskiedenis", as it found its way into school textbooks and into the apartheid created black universities namely the University of the North (for Northern Sotho, Venda and Xhonga ethnic groups); the University of Western Cape (for Coloureds); the University of Durban Westville (for Indians); the University of Zululand (for Zulus, Ndebeles and Zwazis); and the University of Fort Hare which was redefined to cater only for Xhosas. ${ }^{4}$ In order to ensure that "volkgeskiedenis" dominated within these universities, the care of history departments was entrusted to ex-Stellenboschers. ${ }^{5}$ In defining this history that found its way into school textbooks and universities, excluding the English medium universities, Leslie Witz argues that it "... was an uncritical history that glorified an Afrikaner past, verified the British and presented blacks as savage, pagan barbarians. It was the history that had to be accepted without question." ${ }^{6}$ Five Hundred Years, the History of South Africa, written by Afrikaner historians (except for two chapters by English speaking historians) under the editorship of C.F.J. Muller, was for many years considered the Bible of both Afrikaans and black history departments which were dominated by what Francine de Clercq called "verkrampte Afrikaners." 7 In the 1970s People's History took a different turn with the formation of the History Workshop in South Africa.

\section{THE FORMATION OF THE HISTORY WORKSHOP AT THE UNIVERSITY OF THE WITWATERSRAND}

The History Workshop was founded in 1977 by a group of academics drawn from a number of disciplines in the humanities and the social sciences at the University of Witwatersrand in Johannesburg. The time of its formation was a very significant era in South Africa for both the discipline history and the wider South African society were in turmoil. Since the late 1960 s and more particularly the early 1970s a radical critique of liberal and conservative South African historiography had been underway, led by South African scholars based at a number of university centres in England. Prominent amongst these scholars were Shula Marks, Stanley Trapido, Martin Legassick and Harold Wolpe. ${ }^{8}$ Since the 1973 workers' strike in Durban and more particularly since the 1976 students' revolts which started in Soweto and spread to the rest of the country, the South African society was in turmoil. Many observers believed that South Africa would never be the same again. These actions of the ordinary people together with developments in South African historiography, led to the formation of the History Workshop at Wits. The central object of the South African based History Workshop was to promote research into the actions of the ordinary people and make it popularly available to those engaged in the struggle. Historians from the traditionally English medium universities (Wits, Rhodes, Cape Town and Natal) started to write the history of ordinary people. The Wits History Workshop provided historians with an arena for exposing such a history.

Many of the intellectual ideas associated with the formation of the History Workshop, came from outside South Africa: such as the new revisionist history crafted by South African scholars (many who were in exile) in England, as well as the the History Workshop Movement at the Oxford University. ${ }^{9}$ The South African based History Workshop provided a major local focus on a radical South African social history.

A. Grundlingh, Politics, Principles and Problems of a profession: Afrikaner historians and their discipline, c. 1920-1965, Perspectives in Education 12(1), 1990, p 1.

3 A. Grundlingh, Politics, Principles and Problems of a profession: Afrikaner historians and their discipline, c. 1920-1965, Perspectives in Education 12(1), 1990, p 2.

4 For an analysis of the establishment of early apartheid universities and how the University College of Fort Hare was transformed along apartheid lines see D.H. Makobe, A partheid and the University College of Fort Hare, 1950-1965 (Unpublished BA Honours thesis, Rhodes University).

See F.A. van Jaarsveld, Die Afrikaner se Groot Trek na die Stede en ander Opstelle, for details.

6 L. Witz, History of the People, for the People and by the People: A brief examination of the development of People's history in South Africa, 1977-1988, South Africa International, July 1982, p 32.

F. de Clercq. Black Universities as contested terrain: the politics of progressive engagement, Perspectives in Education 12(2), $p$ 58. For criticism on this book see: J. Bergh, The Afrikaans Historian and his work, South Africa International, July 1982, p 35.

See B. Bozzoli and P. Delius, Radical history and South African society, History Workshop editors Introduction, Radical History Review 46(7), 1990.

9 P.Bonner, New Nation: New History, The History Workshop in South Africa, 1979-1994 (Unpublished History Workshop paper, 1315 July 1994 , University of the Witwatersrand), p 2. 
At the time of the formation of the History Workshop at Wits the dominant approach in radical South African historiography was an instrumentalist, structuralist Marxism in which human activity and agency barely figured at all. This may have reflected in part the apparently passive and submissive posture of South Africa's black population in the 1960s and early 1970 s. During the 1973 black workers' strike in Durban and the 1976 students' uprisings, however, class and popular struggles once again stirred. Human consciousness and agency reclaimed their places as important objects of study. ${ }^{10}$ Academics, especially those associated with the History Workshop, started to write the history of ordinary South African people such as mineworkers, domestic servants, traders or the unemployed.

In the 1980s the struggle against apartheid intensified. African students were in the forefront through their rejection of Bantu Education. Lead by the militant Congress of South African Students (COSAS), this took the form of marches, the destruction of public property and above all school boycotts. It is estimated that some 650000 students in hundreds of schools across the country were involved in school boycotts during 1985." Bantu Education, as J. Hyslop concluded, served as an important gravedigger of apartheid during this period. ${ }^{12}$ The slogan "Liberation first Education later" served as the mobilising principle amongst students. The main demand for the mass student boycotts of schools was that Bantu education and apartheid had to be abolished. The state responded by banning the organisation that represented the students, COSAS. Towards the end of 1985 a National Consultative Conference was called by the Democratic Movement formed by United Democratic Front (UDF); COSAS, South African Students Congress (SASCO); Congress of South African Trade Unions (COSATU); civic organisations and other smaller organisations. At this conference it was decided that students would return to school and work towards "education for liberation". The conference resolved to strive actively for People's Education. People's Education was defined as education that "...enables the oppressed to understand the evils of the apartheid system and prepares them for participation in a non-racial, democratic system; eliminates capitalist norms of competition, individualism and stunted intellectual de- velopment and encourages collective imput and active participation by all, as well as stimulating critical thinking and analysis; eliminates illiteracy, ignorance and exploitation of any person by another; equips all sectors of our people to participate actively and creatively in the struggle to attain people's power in order to establish a non-racial democratic South Africa; allows students, parents, teachers and workers to be mobilised into appropriate organisational structures which enable them to enhance the struggle for people's power and to participate actively in the initiation and management of people's education in all its forms; enables workers to resist exploitation and oppression at their work place."13

Arising out of this conference the National Education Crisis Committee (NECC) was formed. ${ }^{14}$ The NECC launched a back to school campaign because it believed that the formal Bantu education system was to be occupied as a terrain of struggle rather than something to be destroyed. In order to implement People's Education programmes in the schools, the NECC in 1986 established Subject Commissions for history, English and mathematics. ${ }^{15}$ Students, workers and ordinary people started to learn more about their history at political rallies, from leaflets distributed during the commemoration of significant political events such as the Sharpeville massacre. They started to learn a history not reflected in their school history books. They welcomed it. John Wright has defined People's History as "...the self-consciously alternative kind of history which in the last year or so has become widely known in South Africa as People's history which has its origins in the post-Soweto period of the late 1970s. It has emerged essentially as antiapartheid history; that is history written explicitly as a counter to the racist and elitist stereotypes and perversions of the Southern African past that have characterised the history propagated, especially in the schools education system, by the successive apartheid regimes. It is popular history in that where apartheid history seeks to minimise and demean the historical roles played by the black people, who form the great majority of South Africa's population, People's History deliberately seeks to bring the black underclasses into South African history, and at the same time is written primarily for a readership drawn from those classes." 16

10 P. Bonner, New Nation: New History, The History Workshop in South Africa 1979-1994 (Unpublished History Workshop paper, 1315 July 1994, University of Witwatersrand), pp 2-3.

11 S. Krige et al, History for the future: taking another look at "what is history", Education Policy Unit, University of Witwatersrand, March 1992, p 2.

12 J. Hyslop, Let us cry for our Children: lessons of the 1955-6 school boycotts, Transformation 4, 1987, p 10.

13 L. Witz, History of the People, for the People and by the People: A brief examination of the development of People's history in South Africa, 1977-1988, South Africa International, July 1982, p 32.

14 For the history of the NECC and subsequent conferences see J. Muller, People's Education for People's Power and the Nationa Education Crisis Commitee: the choreography of educational struggle, South African Review 4, 1987, pp 40-66.

15. The History Commission produced a book entitled: What is History? A new approach to history for students, workers and communities.

16 J.Wright, Popularising the Precolonial past: Politics and Problems, Perspectives in Education 10(2), 1988/89, p 47. 
Knowledge of history, of the resistance to oppression before and after the imposition of apartheid became a major weapon in the struggle for national liberation. It was during this period, as P. Bonner puts it, that "...academics, aspiring academics and activists alike began to perceive a political need for historical and other academic studies both to provide a better understanding of South African society with which to map the way forward and to restore to the mass of the population a history of which they had been deprived."17

The writing of People's History became an intellectual show of solidarity to the masses engaged in the struggle for liberation. It was during this period that academics picked up familiar themes in South African history and reinterpreted them to fit into the political mood prevailing among black South Africans at the time. This trend became known as People's or Popular History. The Bulhoek massacre was one of the topics which was chosen and reinterpreted within the People's History approach.

\section{THE DISTORTIONS OF THE BULHOEK MASSACRE}

There are numerous South African history books which sporadically cover the Bulhoek massacre. ${ }^{18}$ Robert Edgar argues in the introduction of his doctoral dissertation on the Bulhoek massacre entitled The Fifth Seal: Enoch Mgijima, the Israelites and the Bulhoek Massacre, 1921 that most studies which mentioned the Bulhoek massacre, have turned to three sources for their information, namely Monica Hunter's Reaction to Conquest, the Report of the Native Affairs' Commission on the Israelites, and the Report of the Native Churches' Commission. ${ }^{19}$ These sources placed much emphasis on the government's version of the conflict. Historians who referred briefly to the massacre in their studies relied on these three sources for information.

Other studies that provided good material on the Israelites and contain a chronology of how the conflict between the government and the Israelites evolved, are two works, one by W.K. Hancock enticled Smuts: The Fields of force, 1919-1950, vol 2 , while the second is by a German anthropologist, V.K. Schosser, who visited the Israelites in $1953 .{ }^{20}$ G.V. Mqingwana, presently a lecturer in the history department of the University of Transkei, Butterworth branch, wrote his masters thesis at the Northwestern University in the United States of America on the Bulhoek massacre. ${ }^{21}$ He tried to reconstruct the massacre and analysed it in the light of the ethiopianism that emerged in South Africa in the 19th century. He saw the Bulhoek massacre as part of the African resistance to white rule in South Africa and saw those who died at Bulhoek as political heroes. ${ }^{22}$

It is important to note that Mqingwana relied solely on secondary sources for his thesis. The reason being that since 1960 , following the establishment of apartheid universities, African students from South Africa with the assistance of American antiapartheid organisations and the United Nations, started to leave the country and continue with post graduate studies at American universities. Mqingwana was one of those who left to study at an American university. Even if he had stayed in South Africa he would still have had to rely on secondary sources as blacks were not allowed to use the State Archives. He acknowledged this shortcoming by stating that "...this study shall be expanded, modified, or re-organised when more data becomes available." ${ }^{23}$ Since the opening of archival material to all South Africans nothing further on the massacre has appeared from Mqingwana.

A more penetrating analysis of the Bulhoek massacre was done by Robert Edgar in a doctoral dissertation entitled The Fifth Seal: Enoch Mgijima, the Israelites and the Bulhoek Massacre, 1921 at the University of California in the United States of America. In his study Edgar firmly places Enoch Mgijima (and his sect) within a triple context: the Xhosa prophetic tradition, the creation of independent Zionist churches and the pattern of linkages which developed between different groups of African Christians in South Africa and some black American churches during the late nineteenth and

17 P. Bonner, New Nation: New History, The History Workshop in South Africa, 1979-1994 (Unpublished History Workshop paper, $13-$ 15 July 1994 , University of the Witwatersrand), p 3.

18 Such works includes, J. Pampallis, Foundations of the New South Africa, T.R.H. Davenport, South Africa: A Modern history, P.R. Maylam, A history of the African People of South Africa: from the early Iron Age to the 1970s, E. Roux, Time longer than rope, Readers Digest illustrated History of South Africa, the real story.

19 M. Hunter, Reaction to Conquest: effects of Contact with Europeans on the Pondo of South Africa, pp 563-565; The Report of the Native Churches Commission (UG 39 - '25); Interim and final Reports of the Native Affairs Commission and Telegram from Commissioner, South African Police, relative to Israelites at Bulhoek and occurrences in May 1921 (A4-'21)

20 W.K. Hancock, Smuts: The Fields of Force, 1919-1950, vol 2 chapter V; V.K. Schosser, Eingeborenekirchen in Sud - und Sudwes-afrika. pp 8-79.

21 G.V.Mqingwana, The Israelite movement and the Bulhoek episode (Unpublished MA thesis, Northwestern University, Evanston, Illinois, USA).

22 G.V.Mqingwana, The Israelite movement and the Bulhoek episode (Unpublished MA thesis, Northwestern University, Evaston, Illinois, USA) p 84.

23 G.V. Mqingwana, The Israelite movement and the Bulhoek episode (Unpublished MA thesis, Northwestern University, Evaston, Illinois, USA), p 2. 
early twentieth centuries. In his study Edgar used important sources of information on the Israelites which had not been consulted previously by scholars, namely written and oral evidence from the Israelites themselves. He recorded some of the problems that he experienced in collecting oral evidence among the Israelites as well as the validity of such evidence. Following his doctoral study he detailed the life of Enoch Mgijima, the origins and development of his church and his end of the world prophecies, as well as the social, political, and economic conditions that gave impetus to his sect's chiliastic expectations which set the scene for its tragic confrontation with the Police. ${ }^{24}$

In the late 1980's history as a discipline became so crucial that the New Nation, a radical newspaper promoting the struggle for national liberation, in cooperation with the Wits History Workshop started to produce a People's History page in the newspaper. The People's History pages, which were produced as part of a learning nation section within the newspaper, proved to be so popular with New Nation readers that the Wits History Workshop together with New Nation decided to re-issue them in bookform in $1989 .{ }^{25}$

Robert Edgar, as his contribution to the People's History, produced a booklet as part of the Wits History Workshop Topic Series 1 on the Bulhoek massacre. ${ }^{26}$ The booklet was aimed at a wider audience, including the workers, radical students and teachers who were engaged in the struggle for national liberation.

In his inaugural lecture at Rhodes university, P.R. Maylam, head of the history department argued that "...historians must persist in addressing themes which have been better worked but which are still not properly understood... Historical writing will always be contested terrain. This contestation has to be acknowledged in historical texts; it must not be suppressed."27 This also applies to the Bulhoek massacre. Much work has been done on the incident, but it needs to be carried further still.

The writer on the Bulhoek massacre avoids duplicating what has already been written on the incident. The Israelites are not located within the Xhosa prophetic tradition that prevailed in the Eastern Cape at the time. ${ }^{28}$ The research focuses on the fanatical nature of the Israelites, and analyses how this attitude lead to the massacre. ${ }^{29}$

Although the Bulhoek massacre has been the subject of study for both a masters thesis and a doctoral dissertation, a number of questions remain unsolved. ${ }^{30}$ Until recently different estimates of the number of Israelites who lost their lives at Bulhoek were given in South African history books. ${ }^{31}$ Even some of the Israelites who survived the massacre could not remember the exact number of fellow Israelites who died at Bulhoek. Rubin Nxopo, who was 16 years old at the time of the incident, alleges that hundreds of Israelites died during the massacre..$^{32}$ This has added more confusion on the estimates of Israelites who lost their lives at Bulhoek. The writer attempted resolving this question by comparing documentary evidence on the subject. ${ }^{33}$ Documentary evidence on the Bulhoek massacre was more reliable in establishing an exact figure.

In his analysis of the Bulhoek massacre, Vuyani Mqingwana, saw a link between Bulhoek and later African nationalistic resistance that culminated in the Sharpeville massacre of $1960 .{ }^{34}$ However, he does not in any fashion substantiate this link nor the relationship of the Israelite sect with the South African Native National Congress (SANNC). It is difficult (without establishing such a relationship) to see the Israelites as political heroes who died in the struggle for national liberation. It is this writer's contention that the Israelites who died at Bulhoek were not political heroes but were religious fanat-

24 R.R. Edgar, The prophet motive: Enoch Mgijima, the Israelites, and the background to the Bulhoek massacre, International Journal of African Historical Studies 15(3), 1982.

25 See New Nation, New History.

26 R.R. Edgar, Because they chose the plan of God, the story of the Bulhoek massacre.

27 P.R. Maylam, History after apartheid, Inaugural lecture, Rhodes University, Grahamstown, 24 March $1993, \mathrm{p} 7$.

28 For an analysis of the Xhosa prophetic tradition that prevailed in the Eastern Cape at the time of the Bulhoek massacre, see R.R. Edgar, The Fifth Seal: Enoch Mgijima, the Israelites and the Bulhoek massacre (Unpublished PhD disertation, University of California, Los Angeles, USA); G.V. Mqingwana, The Israelite movement and the Bulhoek episode (Unpublished MA thesis, Northwestern University, Evanston, Illinois, USA).

29 D.H. Makobe, Confrontation with the Police: The Israelites of Enoch Mgijima and the Bulhoek massacre of 24 May 1921, Militaria 26(1), 1996, p 22.

30 See G.V. Mqinqwana, The Israelite movement and the Bulhoek episode(Unpublished MA thesis, NorthwesternUniversity, Evanston, Illinois, USA); R.R. Edgar, The Fifth Seal: Enoch Mgijima, the Israelites and the Bulhoek massacre(Unpublished PhD dissertation, University of California, Los Angeles, USA).

31 D.H. Makobe, The price of fanaticism: The casualties of the Bulhoek massacre, Militaria 26(1), 1996, pp 39-41.

${ }_{32}$ East London Museum, East London: The warrior who survived at the last stand of the Israelites, Sunday Star, 1992-06-26, $\mathrm{p}$ 10.

33 D.H. Makobe, The price of fanaticism: The casualties of the Bulhoek massacre, Militaria 26(1), 1996, pp 39-41.

${ }^{34}$ G.V.Mqinqwana, The Israelite Movement and the Bulhoek episode(Unpublished MA thesis, Northwestern University, Evanston, Illinois, USA), p 84 
ics who were driven by their fanaticism and blind faith in Enoch Mgijima. ${ }^{35}$ This fact is clearly illustrated by evidence submitted to Sir Thomas Graham, the presiding judge at the trial of the Israelites.

In most historical works the blame for the Bulhoek massacre is placed on the shoulders of the Police without regards to the facts. In a book that was originally written as a textbook for the exiled South African students at the ANC's Solomon Mahlangu Freedom College in Tanzania, J. Pampallis said this about the massacre: "In May 1921 the Smuts government sent 800 police armed with rifles and machine guns to Bulhoek. The Israelites were ordered to leave, but they replied that Jehovah (God) said they should not allow themselves to be forced to move or allow the police to arrest anyone. They then charged the police with spears and sticks. The police fired no warning shots, waiting until the Israelites were just a few yards away." ${ }^{36}$

An analysis of how the Bulhoek massacre took place differs fundamentally from Pampallis's analysis. The Police fired one volley in the air when the Israelites began to advance at a very fast pace towards the Police. Recognising that the Israelites were not deterred, the Police started to open fire. ${ }^{37}$ It is a historical fact that the Israelites were not carrying only sticks when they charged at Police. They carried swords, knobkieries, spears and other miscellaneous home made weapons. ${ }^{38}$ This is one of the facts that illustrates how historians have distorted the Bulhoek massacre.

Another area of the massacre which is distorted in all the works that focus on Bulhoek, is the reactions of the different sectors of society during that period towards the Bulhoek massacre. The views of the people who lived in the vicinity of Bulhoek during the time, as well as those of the general public towards the Israelites, is totally neglected in historical studies. Following the massacre, people who lived next to the Israelites, (members of the various blocks of Kamastone location, white farmers and the white community of Queenstown) held a number of meetings expressing their opinions. A number of letters were written to various newspapers by the members of the general public. ${ }^{39}$ Robert Edgar referred briefly to this aspect by selecting the views of political parties that sympathised with the Israelites. For those who critised the Israelites he only referred to D.D.T. Jabavu, J.T. Jabavu and to General J.B.M. Hertzog's opinion on the incident. No mentioned is made of the opinion of people who lived closer to the Israelites or the members of the general public. ${ }^{40}$ The writers research has corrected such a distortion by focusing generally on the reactions of the public towards the incident. ${ }^{41}$ The main aim of Edgar was to show the Bulhoek massacre as part of the political history of Africans by selecting only the views of political parties.

\section{CONCLUSION}

Since the 1930s until late 1980s, historical writing in South Africa has been shaped by present politi$\mathrm{cal}$ and ideological considerations. During the era of the National Party government historical writing in South Africa was dominated by Afrikaner historians. History as a discipline was used to promote Afrikaner nationalism. It was during this period that black South Africans picked up distorted assumptions of South African history, assumptions which have become deeply ingrained and which have served to reinforce the established political order.

In the 1980s history was used as a weapon in the struggle for national liberation. Academics picked familiar themes in South African history and reinterpreted them to fit into the People's History approach. The History Workshop at the University of Witwatersrand promoted such a history.

The Bulhoek massacre represents an example of how history as an academic discipline was used to. further the goals of the struggle for national liberation. This was especially so in the 1980s when calls for the creating of a People's History was made. Historians should strive for academic excellence in their work rather than attempt to legitimate the policies and leaders of the ruling parties.

\section{BIBLIOGRAPHY}

\section{SECONDARY SOURCES}

\section{EAST LONDON MUSEUM, EAST LONDON \\ The warrior who survived at the last stand of the Israelites. Sunday Star, 26 June 1992.}

Interim and final Reports of the Native Affairs Commission and Telegram from Commissioner, South African Police, relative to

35 D.H. Makobe, Confrontation with the Police:The Israelites of Enoch Mgijima and the Bulhoek massacre of 24 May 1921 , Militaria 26(1), 1996, pp 22 - 37

36 J. Pampallis, Foundations of the New South Africa, p 115.

37 D.H. Makobe, Confrontation with the Police: The Israelites of Enoch Mgijima and the Bulhoek Massacre of 24 May 1921 , Militaria 26(1), 1996, pp 22-37.

38 Weapons used by the Israelites at Bulhoek are exhibited in Kaffraria Museum, King Williams Town while others are at the Africa Museum, Johannesburg.

${ }^{39}$ See D.H. Makobe, Understanding the Bulhoek massacre: Voices after the massacre and down the years, Militaria 26(2) 1996.

${ }^{40}$ R.R. Edgar, Because they chose the plan of God: the story of the Bulhoek massacre, pp 35-39.

${ }^{41}$ See D.H. Makobe, Understanding the Bulhoek Massacre: Voices after the massacre and down the years, Militaria 26(2), 1996 
Israelites at Bulhoek and occurrences in May, 1921 [A4 - '21] (Cape Town, 1921).

The Report of the Native Churches Commission [UG 39 - '25] (Cape Town, 1925).

BERGH, J., The Afrikaans Historian and his work. South Africa International, July 1982.

BOZZOLI, B. and P. Delius. Radical history and South African society. Radical History Review 46(7), 1990.

DE CLERCQ, F., Black universities as contested terrain: the politics of progressive engagement. Perspectives in Education 12(2), 1989/90.

DU TOIT, A., Facing up to the future: some personal reflections on the predicament of Afrikaner Intellectuals in the legitimation crisis of Afrikaner Nationalism and the Apartheid state. Social Dynamics 7, 1981.

EDGAR, R.R., The prophet motive: Enoch Mgijima, the Israelites and the background to the Bulhoek massacre. International Journal of African Historical Studies 15(3), 1982.

GRUNDLINGH, A., Politics, Principles and Problems of a profession: Afrikaner historians and their discipline, c. 19201965. Perspectives in Education 12(1), 1990.

HYSLOP, J., Let us cry for our Children: lessons of the 1955-6 school boycotts. Transformation 4, 1987.

MAKOBE, D.H., Confrontation with the Police: The Israelites of Enoch Mgijima and the Bulhoek massacre of 24 May 1921. Militaria26(1) 1996.

MAKOBE, D.H., The price of fanaticism: The casualties of the Bulhoek massacre. Militaria 26(1) 1996.

MULLER, J., People's Education for People's Power and the National Education Crisis Committee: the choreography of educational struggle. South African Review 4, 1987.

WITZ, L., History of the People, for the People and by the People: A brief examination of the development of People's history in South Africa, 1978-1988. South African International, July 1982.

WRIGHT, J., Popularising the Precolonial past: Politics and Problems. Perspectives in Education 10(2), 1988/89.

ADAM, H., and H. GILIOMEE, The Rise and Crisis of Afrikaner Power. Cape Town, 1979.

BONNER, P., New Nation, New History, The History Workshop in South Africa 1979-1994, Unpublished History Workshop paper, University of Witwatersrand, 13-15 July 1994.
DAVENPORT, T.R.H., South Africa: A Modern history. London, 1991.

EDGAR, R.R., Because they chose the plan of God, the story of the Bulhoek massacre. Johannesburg, 1988.

EDGAR, R.R., The Fifth Seal: Enoch Mgijima, the Israelites and the Bulhoek massacre, 1921. Unpublished PhD dissertation, University of California, Los Angeles, USA, 1977.

HANCOCK, W.K., Smuts: The Fields of Force, 1919-1950 vol 2, Cambridge, 1968.

HUNTER, M., Reaction to Conquest: effects of Contact with Europeans on the Pondo of South Africa. London, 1970.

KRIGE, S., N. TAYLOR and I. VADI, History for the future: taking another look at "what is history". Education Policy Unit, University of Witwatersrand, March 1992.

MAKOBE, D.H., Apartheid and the University College of Fort Hare. Unpublished BA Honours thesis, Rhodes University, 1994.

MAYLAM, P.R., A history of the African People of South Africa: from the early Iron Age to the 1970's. Cape Town, 1986.

MAYLAM, P.R., History after apartheid, Inaugural lecture, Rhodes University, Grahamstown, 24 March 1993.

MOODIE, T.D., The rise of Afrikanerdom: Power, Apartheid and the Afrikaner Civil religion. Berkeley, 1975.

MQINGWANA, G.V., The Israelite movement and the Bulhoek episode. Unpublished MA thesis, Northwestern university, Evanston, Illinois, USA, 1975.

New Nation, New History, vol 1, Johannesurg, 1989.

O'MEARA, D., Volkskapitalisme: Class, Capitalism and Ideology in the Development of Afrikaner Nationalism, 1934 1948. Johannesburg, 1983.

PAMPALLIS, J., Foundations of the New South Africa. Cape Town, 1991.

Readers Digest illustrated History of South Africa, the real story. Expanded second edition Cape Town, 1988.

ROUX, E., Time longer than rope. Wisconsin, 1964.

SCHOSSER, V.K., Eingeborenenkirchen in Sud - und Sudwes-afrika. Kriel, 1958.

VAN JAARSVELD, F.A., Die Afrikaner se Groot Trek na die Stede en ander Opstelle. Johannesburg, 1982.

What is History? A new approach to history for students, workers and communities. Johannesburg, 1987. 